This article was downloaded by: [University of Toronto Libraries]

On: 20 December 2014, At: 12:57

Publisher: Routledge

Informa Ltd Registered in England and Wales Registered Number: 1072954

Registered office: Mortimer House, 37-41 Mortimer Street, London W1T

3J H, UK

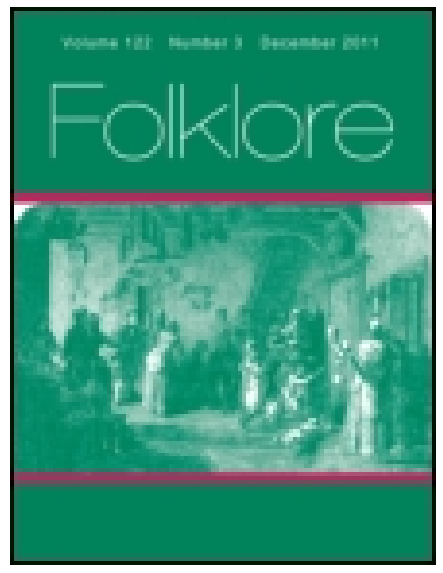

\title{
Folklore
}

Publication details, including instructions for authors and subscription information:

http:// www. tandfonline.com/loi/ rfol20

\section{St. Nicolas and Artemis}

Eugene Anichkof

Published online: 14 Feb 2012.

To cite this article: Eugene Anichkof (1894) St. Nicolas and Artemis, Folklore, 5:2, 108-120, DOI: 10.1080/ 0015587X.1894.9720212

To link to this article: http:// dx. doi.org/ 10.1080/ 0015587X.1894.9720212

\section{PLEASE SCROLL DOWN FOR ARTICLE}

Taylor \& Francis makes every effort to ensure the accuracy of all the information (the "Content") contained in the publications on our platform. However, Taylor \& Francis, our agents, and our licensors make no representations or warranties whatsoever as to the accuracy, completeness, or suitability for any purpose of the Content. Any opinions and views expressed in this publication are the opinions and views of the authors, and are not the views of or endorsed by Taylor \& Francis. The accuracy of the Content should not be relied upon and should be independently verified with primary sources of information. Taylor and Francis shall not be liable for any losses, actions, claims, proceedings, demands, costs, expenses, damages, and other liabilities whatsoever or howsoever caused arising directly or indirectly in connection with, in relation to or arising out of the use of the Content.

This article may be used for research, teaching, and private study purposes. Any substantial or systematic reproduction, redistribution, reselling, loan, sub-licensing, systematic supply, or distribution in any form to anyone is 
expressly forbidden. Terms $\&$ Conditions of access and use can be found at http://www.tandfonline.com/page/terms-and-conditions 


\section{ST. NICOLAS AND ARTEMIS.}

BY EUGENE ANICHKOF.

In the Middle Ages the belief in St. Nicolas, Archbishop of Myra in Lycia, as a patron of sailors was widely spread. Many churches were built in his honour on the sea-shore. ${ }^{1}$ Among his numerous miracles, many were supposed to have been worked at sea. It is, for example, related that a merchant, before embarking on a ship, went to the church of St. Nicolas at Constantinople, and there prayed eagerly. When he was at sea the weather suddenly became very rough, and he was threatened with great danger. But St. Nicolas did not forget the prayers addressed to him, and abated the storm. ${ }^{2}$ Many similar miracles could be added. ${ }^{3}$

The old French romance of St. Nicolas, by Wace, relates an analogous miracle. Once a ship was in great danger-

"Donc comencent tuit a crier,

Deu e ses sainz a reclamier.

Mult se cleiment cheitif e las

Sovent crient : seint Nicholas, Socour nus, seint Nicholas sire, Se tiels es cum oomes dire!

A tant uns hom lor aparut Qui en la nief od els estut, Et itant at a els parlie;

Io sui que m'avez appelé

Isnel le pas l'orez cessa

E saint Nicholas s'en ala."4

1 Hampson, Medii aevi Kalendarium. London, 184I, vol. i, p. 69 .

2 A Slavonic Prologue. St. Petersburg, 1817.

- For other Slavonic texts translated from Greek, see Arch. Leonid., Posmertnya chudesa sv. Nikolaia, Pamiatniki Drevnei Pismennosti, 1888, pp. 2 and 33 ; and my study, Mikola the Divine (Ugodnik) and St. Nikolas, in the Memoirs of the Society of Modern Philology, St. Petersburg, 1892, pp. 17 and 32. Compare Assemani Kalendaria Ecclesiae Universae, Romae, 1755, v, p. 420.

4 Maistre Wace's St. Nicolas herausg.v. Dr. Delius. Bonn, I850, 250-260; compare 804-924. 
A Serbian carol represents him in constant activity at sea. Once all the saints were enjoying wine together; when the cup out of which they all drank in turn reached St. Nicolas he was too sleepy to hold it, and let it drop. St. Elias shook him by the arm, and aroused him. "Oh! I beg the company's pardon", said St. Nicolas, "but I have been very busy, and was absent from your festival. The sea was rough, and I had to give my help to three hundred ships that were in danger; that is the reason of my being tired, and letting the cup fall out of my hands." 1

In Russia you will always find an "ikon" of St. Nicolas in every merchantman. ${ }^{2}$ In Germany it was customary for sailors who had escaped shipwreck to dedicate a piece of old sail to St. Nicolas. ${ }^{3}$

In studying those Christian saints, who play a great part in the Christian mythology, the school of Grimm tried to find what heathen gods they replaced. In this way, St. Nicolas turns out to be a substitute of Neptune, ${ }^{4}$ or of Odin, ${ }^{5}$ or of Fro. ${ }^{6}$

Mr. Zingerle ${ }^{7}$ has lately proposed a new hypothesis. After drawing our attention to a number of analogies, known already to other investigators, ${ }^{8}$ between St. Nicolas and Nikuz, Hnikor, Nix, he differentiated Nikuz from Odin, and concluded that Nikuz is at the root of all representations that are connected with the name of St. Nicolas." "Even the names," says Mr. Zingerle, "are

Karadjich, Srpske Narodne piesme, ii, p. 100.

Tereshchenko, Byt russkago naroda, vol. vi, p. 46.

Hampson, l. $c$.

B. Schmidt, Volksleben der Neugriechen, S. 37.

Simrock, Handbuch der deutschen Mythologie, Bonn, 1887, S. 446 and 549. E. H. Meyer, Germanische Mythen, Berlin, 1891, S. 257.

T. W. Wolf, Beiträge zur deutschen, Mythologie. Göttingen, 1882, S. I 24.

Zeitschrift für Volkskunde, ii Band, 9 Hèft.

Hampson, l. c., vol. i, p. $68 \mathrm{ff}$.

- Compare Simrock, l. c.: "Ob Odins Namen Hnikor und Nikuz 
strikingly alike. But also the appearance of the saint has an analogy to that of the Waterman. The long grey beard is an attribute of the saint. We generally see Nix the Waterman also represented with a long beard." I I think it unnecessary to divell on the superficial character of the analogy just quoted. All Eastern saints, if aged, are represented with beards, and the Byzantine images-of St. Nicolas belonging to the fifth century ${ }^{2}$ of course represent him with a beard, but generally a short round one. In this case why should St. Nicolas more than any other saint make us think of the Waterman?

The other argument brought forward by Mr. Zingerle is not of more value. "The souls of the drowned are kept by Nix in pots. When we remember," continues Mr. Zin: gerle, "that souls were generally represented in the shape of children, we find that the pots of the Waterman have an analogy to St. Nicolas' tub, containing three children."

The picture of St. Nicolas standing near a large tub, with three youths in it, has its origin in the legend of a miracle, in which St. Nicolas raised from the dead three young men, who were killed and robbed by an innkeeper in Myra. Their bodies were cut to pieces and thrown into a tub. St. Nicolas prayed over the tub, and the youths came to life again. This story is found in almost all countries in the Middle Ages. ${ }^{4}$ It is undoubtedly of Greek origin, and taken from the saint's life.

It lies at the root of the saint's fame as a friend of

ihn als Wassergott bezeichnen ist zweifelhaft, doch würde sich daraus noch besser erklären, warum der $h$. Nicolaus auf einem Schimmel geritten kommt und als Patron der Schiffer gilt."

1 Zingerle, l. c., in Heft, S. 410.

2 Jahrbücher für protestantische Theologie, xIII Jahrgang, iii Heft, S. 523 ; see Görres' article.

${ }^{3}$ Loc. cit., S. $4 \mathrm{I} 2$.

4 Mikola Ugodnik and St. Nicolas, p. 19. See also Hampson, l. c., p. $77 \mathrm{ff}$; Th. Wright, Songs and Carols, etc., of the XVth Century, Worton Club ed, London, 1856; and Zingerle's article, p. 332 ; Robert Wace's St. Nicolas. 
children. ${ }^{2}$ We may add that the fixing of St. Nicolas' Day on the 6th of December had a great influence in confirming this idea; December being, as pointed out by Prof, Vesselovsky, the special month of children's feasts. ${ }^{2}$

The representation of this miracle in an image or picture thay, if we strain our imagination to the utmost, make us think of the Waterman with the souls of the drowned. But the resemblance is purely accidental. Moreover, this miracle is quite lost in the mass of the saint's other miracles, and has never, so far as I know, been chosen as the subject of a separate representation, but only has its place among a number of miniature pictures in a series forming one "ikon".

So far the resemblance between the names of Nikuz and St. Nicolas, and the marine activity of the saint, remain unexplained. To explain both we must make a detailed inquiry into the life and Lycian cult of St. Nicolas. There we may perhaps trace the relation between the Christian cult and some ancient Greek cult it has replaced. In the life of St. Nicolas we find two suggestions of ancient mythology. First, the festivals of the Rosalia (dies Rosarum) are mentioned: "When came the time of the

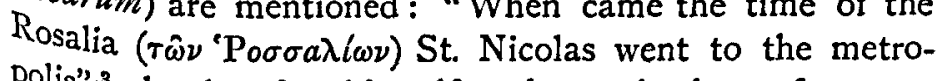
polis'; 3 he therefore himself took part in the performance of a heathen rite. We must not be surprised to find a mention of the Rosalia in Lycia. The Rosalia were a Thracian spring-festival, imported thither, it is said, from Phrygia.4 Secondly, we hear of the strife between our saint and
Artemis. It is written in the Vita that St. Nicolas de-

\footnotetext{
1 See Hampson, l. c., and Eug. Schnell, Sanct Nicolaus der heilige

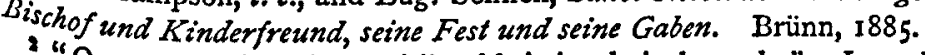
"Opyty po istorii razvitiia khristianskoi legendy" Jumal Ministerstva Narodnago Prosvieshchenia, vol. 184, pp. 272-288.

Trudy Kiefskoi Dukhovnoi Akademii, 1873, xii.

Tomaschek, Rosalia und Brumalia, in the Sitzungsberichte der K. Wiener Akademie, Band 60, S. 352, etc.
} 
molished the Temple of Artemis, and out of vengeance the goddess gave to pilgrims on the road to Myra some oil that was to burn the church of the saint. But the saint appeared to them when they were at sea, and commanded them to throw the oil overboard. They obeyed, and the oil burned on the surface of the water with an infernal flame. ${ }^{1}$ In a Syriac text of the British Museum this Artemis is called Mater Deorum. ${ }^{2}$ She evidently is not the Greek, but the Ephesian, Artemis; not a virgin like the former, but a symbol of motherhood, as is plainly shown by her being represented with many breasts. ${ }^{3}$ "The goddess of Ephesos is the goddess of fecundity, as her attributes indicate." She is thus related to the goddesses of Asia Minor, Cybele and Anaitis, who are also akin to the Greek Aphrodite. In the town of Perga, in Pamphilia, a coin was stamped with the representation of the Pergasian Artemis, very like the goddesses of Love and of Fecundity of Asia Minor. ${ }^{5}$

The cult of the Ephesian Artemis is at once Eastern and Greek; as lunar deities, Anaitis and Cybele were confounded with the Moon-goddess Artemis, who in her turn received from them qualities foreign to her original nature. ${ }^{6}$ Hence the difference between the Ephesian goddess and her Greek namesake. In Armenia there was a goddess called Artemis-Anaitis, and her cult had a purely bacchic character." From Cybele and Anaitis there is but one step

1 Migne, Patrologiae Cursus Completus, Series Graeca, t. ${ }^{116}$; Simeonis Metaphrastae opera, p. 354 ; Legenda Aurea Iacobis da Voragine. Lipsiae, 1846 , p. 24.

2 Addit. Cat. of Syriac MSS., No. 14,645, printed in vol. viii of the Memoirs of the Oriental Section of the Imperial Archæological Society of St. Petersburg.

${ }^{3}$ O. Seyffert, $A$ Dictionary of Classical Antiquities. London, 1891 , p. 72.

\footnotetext{
- Maury, Histoire des religions de la Grèce, etc., t. iii, p. 155.

- Texier, L'Asie Mineure, p. 599.

- Guhl, Ephesiaca, Berlin, 1843, p. II9 ; and Maury, l. c.

7 Guhl, p. 168.
} 


\section{St. Nicolas and Artemis.}

to the Mater Deorum; indeed, Strabo made no difference between the Mater Deorum and Cybele. ${ }^{1}$

The cult of all these divinities is concentrated in the south of Asia Minor. The Mater Deorum was a goddess of Phrygian origin.2 Besides the Artemis of Perga, on the south coast of Asia Minor, several other like-named deities, reminding us in varying degrees of Ephesian Artemis, were worshipped ${ }^{3}$ in this district, where also many material remains of Cybele and Anaitis cults have been found. ${ }^{4}$

The close connection of these goddesses will be still more evident if we consider the manner in which the festivals in their honour were celebrated. At the festival of Artemis of 'Ephesos "representations of the goddess were borne in triumphal procession, and hymns in her praise were sung. Some of the people who took part in the procession were dressed in fantastic costumes .... they indulged in ludicrous and indecent pantomime, much as is the case later in similar processions of the Middle Ages." This description recalls the processions in honour of the Mater Deorum. ${ }^{6}$ The Thracian festivals in honour of Dionysos and the festival of Roses (dies Rosarum, Rosaria, Rosalia) had the same bacchic character with orgiastic processions and dances. 7 Flowers played a great part in all these festivals-wreaths and garlands, paths strewn with roses, representations of goddesses decked with flowers. ${ }^{8}$ Roses were essentially a Phrygian ornament; the famous Rosae centifoliae, reputed to be Thracian, were correlated with the myth of Midas, in other words, with Phrygia." The geographical situation of Phrygia and Lycia favoured

X, I5; quoted by Maury, l. c., p. 80.

2 Goehler, De Matris Magnae apud Romanos cultu, Lipsiae, 1886,

p. 3.' "Cybele erat summa Phrygum dea," Strabo, $x$.
Maury, l. c., p. I64.
Maury, l. c., p. 158.
Réville, La religion a Rome, etc., p. 63, etc.
Tomaschek, l. c., S. 352.
Ibid., S. 356 .
Texier, $l$. $c$.
VOL', $\mathbf{}$.
Ibid., S. 355 . 
frequent intercourse between them. Myra seems to have been the chief seaport of Phrygia. ${ }^{1}$

We have thus succeeded in establishing some solidarity between three cults mentioned in our Vita: those of Artemis, of the Mater Deorum, and of the Rosalia. On all three festivals a gay and profligate crowd, with floweradorned heads, whirls past in dance and pantomime to the sound of songs and flutes.

Concerning the dates of the festivities referred to, we cannot, unfortunately, come to such positive conclusions. The Artemision corresponds to the end of April or the beginning of May. ${ }^{2}$ The date of the festival itself was probably subject to change, and it took place sometimes at the beginning, sometimes at the end, of that month. The date of the Rosalia and of the feast of the Mater Deorum varied still more. We can only assert that both were spring festivals, and may have been celebrated about the beginning of May. ${ }^{3}$

If we bear in mind that St. Nicolas' Day in the Eastern Church was the 9 th of May as well as the 6th of December, we may find a new coincidence between Artemis and our saint. It is generally said that the 9 th of May. was honoured by the Church in remembrance of the removal of St. Nicolas' relics to Bary in the eleventh century, ${ }^{4}$ but the special circumstances of the origin of that feast are unknown, and, in spite of all that has been said, the most plausible hypothesis is perhaps. that it was a continuation of the local spring festival in Myra, that is, the Rosalia.

Artemis of Ephesos, sharing the character both of the Greek virgin goddess and of Aphrodite, is partly a sea and a river goddess, whence her epithet, Potamia. Temples in her honour were often built near springs and rivers. ${ }^{5}$ This

1 Migne, l. c., vol. n16, p. 386.

2. Seyffert, l. c., p. 71 ; Guhl, l.c.

- Tomaschek, l.c.; Goehler, l.c.

4. Shliapkin, Russkoe Pouchenie xi vieka, etc. Pam. rev. pism. I88r.

S Guhl, l. c., p. 85, etc. 
supplies a new connection between her and St. Nicolas; both are not only spring, but also sea deities. ${ }^{1}$

There is of course no external likeness between the beautiful Greek goddess and the grey-bearded saint, but many of their attributes are alike. Artemis-Cybele is often represented as a sea-monster, with the tail of a fish ${ }^{2}$; traces of a legend of St. Nicolas in Sicily seem to indicate a similar conception of him, ${ }^{3}$ and Sicily must be considered as the starting point from which this legend-of a probably Greek origin-began to spread. In France, "une bête terrible qui prend les petits pêcheurs, qui vont se promener sans permission au bord de l'eau à la nuit tombante, s'appelle St. Nicolas: elle est armée de griffes et déchire la figure des enfants attardés sur les grèves."

This description reminds us of a passage in Beowulf : swylce on naesshleo ${ }_{u m}$ nicras licgean bâ on undern-mâtl oft bewitiga $\delta$ sorh-fulne sî̀ on segl-rāde.

In Germany millers throw different things into the water on the 6th of December, St. Nicolas' Day, as an offering to the water-deity. ${ }^{6}$ In Northern countries millers are par-

1 On sea and spring cults of St. Nicolas, see Mikola Ugodnik, etc., pp. I I-20, and 37-51; and Hampson, l.c., pp. 67-72: "According to Hyginus, the privilege of preserving mariners from storm at sea was conferred upon Anaitis by Neptune, who was also one of the Cabiric deities, and whose festivals, the Neptunalia, were celebrated on the 5 th, as that of St. Nicolas was on the 6th, December." This coincidence of both feasts is less suggestive, because Neptune is not mentioned in the Life of the saint. Neither do we know anything about the cults of Neptune in Myra.

2 Guhl, ibid., p. 9 r.

3 "There is some ground to believe that an echo of the name- and sea-cult of St. Nicolas lives under the name of Nicolo-Pesce, hero of a Sicilian legend that has inspired Schiller with his Der Taucher," says Prof. Vesselovsky, Jurnal Ministerstva Narodnago Prosvieshchenia, vol. 168, 1890, p. 2. See also Archivio per lo studio delle Tradizioni populari, viii, p. 3 ; and ix, p. 377, Lu Piscicola e il Cola Pesce.

Revue des Traditions populaires, i, p. 7 .

Beowulf, I428-1430.

- Zingerle, l. c., p. 416. 
ticularly afraid of a certain deity, Neck. ${ }^{1}$ Besides Nicor and Neck, who remind us of St. Nicolas as a sea-monster, the very name of Nicolas is used in a similar signification, but only in its diminutives. For instance, in Germany the sea-deity is sometimes called Nickel or Nickelmann,, and in England Old Nick is a familiar name of the Evil Spirit. ${ }^{3}$ The third diminutive of St. Nicolas, Klaus, is only found in the child-cult of our saint-" der böse Klaus."4

Artemis of Ephesos, as most sea-deities, is sometimes represented on horseback ${ }^{5}$; so is also sometimes St. Nicolas, he being a patron of horses. ${ }^{6}$

After all that has been said, we may, I think, draw the conclusion that the Christian cult of St. Nicolas has, as a whole, replaced that of Artemis of Ephesos. We must bear in mind that the position of the town of Myra as a sea-station between Antioch, Alexandria, and Jaffa from. one side, and Constantinople and Italy from the other, was particularly favourable ${ }^{7}$ to a sea-cult.

In the description of sea-miracles ships are generally supposed to sail from Venice, Antioch, Alexandria, or Constantinople, laden with corn; they sail from east to west, passing $\mathrm{Myra}^{8}$ on the way. St. Paul was twice in Lycia, and on both occasions saw at Myra, or at Patara, ships.

1 E. H. Meyer, Gernanische Mythen, Berlin, I8gr, S. I3r.

2 Simrock, l. c.; and Grimm, Deutsches Wörterbuch, 1889, S. 733.

3 "Several appellations are proper names of men bestowed on the Evil Spirit ...... such are the Engl. 'Old Davy', 'Old Nick' (Nicolas), though there may be also allusion to Hnikor." (Grimm's Mythology, Engl. ed., p. 1004.)

4 Jbid., p. 5 I4.

- "Diese Artemis Potamia war, wie alle Wassergottheiten, auch Rossegöttin." (Mueller, Ant., \$363; Guhl, ibid.)

- See Zingerle, l. c., S. 4II ; and Mikola Ugodnik, etc., pp. 39-40. I was told by Prof. Volodimirof of Kief that there is an image in the West of Russia representing St. Nicolas on horseback ; but, personally, I have never seen such an image.

'See Mikola Ugodnik, etc., p. 14.

- See my Syriac legend, quoted above, and Wace's St. Nicolas; Legenda Aurea, p. 24, and other sea miracles quoted above. 
laden with corn for Italy or Antioch. ${ }^{1}$ A glance at the map explains at once how easily Myra became an important shipping centre. In more recent times-for instance, during the Crusades-Myra had probably not yet entirely lost this position, for it is mentioned as a seaport on two occasions : in the twelfth century, when some merchants of Bari came to Myra and transferred to their own town the relics of the saint ${ }^{2}$; and in the twelfth century, when it is mentioned in the Itinerarium of the German Emperor, Frederick II. ${ }^{3}$

People not only came to Myra for business : we often read in his legend of pilgrimages made to the relics of the saint. For example, Wace says :

"De meint leu e de meinte terre

Vindrent gent le cors seint requerre

$E$ seint Nicolas depreier

$\mathrm{E}$ faire offrende a sun mustier."

I wish to show by these geographical notes that the cult of St. Nicolas, under these circumstances, could spread early and widely among sailors, not only in the East, but also in the West of Europe. The connection of St. Nicolas as a sea-patron having once sprung up, his miracles in that province are easily accounted for.

We may perhaps now succeed in explaining the likeness of names between St. Nicolas and Nikuz, Nicor, Nix. If in France St. Nicolas happens to have been a sea-monster, it is not unlikely that his name was also transferred to the sea- and water-deity of the Germans. We may then, perhaps, reverse Mr. Zingerle's hypothesis. St. Nicolas has not taken the place of the old god Nikuz, but the popular idea of St. Nicolas created the deity Nikuz in the same way that the Slavonian St. Vlassii (Blase) has perhaps helped

I The Acts of the Apostles, xxvii, 37 .

3 Shliapkin, $l$. c.

3 Prutz, Kulturgeschichte der Kreuzzüge, S. 102

- Wace's St. Nicolas, 1080-1084; comp. 804-924. 
to create the god Voloss, ${ }^{1}$ or, as the same St. Nicolas is called by the Siberian idolaters, the Russian god Nicola.

Two very suggestive remarks were made to $\mathrm{me}^{2}$ against the liberty I allowed myself to take with Mr. Zingerle's hypothesis. I was asked, in the first place, if the cult of St. Nicolas had spread wide enough in the eighth century, when we find the first mention of Nicor in the Beowulf, to become a mere common noun indicative of sea-monsters in general; and, secondly, if I could explain, etymologically, Nicolas $=$ Nicor.

The first question slightly puzzles me. I know no written Vita of St. Nicolas earlier than the eighth century. My Syriac text dates from the ninth century, ${ }^{3}$ and, therefore, gives us ground for believing that its Greek original belongs to the eighth century; the panegyric of Methodius the Patriarch ${ }^{4}$ also refers to a Vita written in the eighth century; and in the Chronicle of Theophanes ${ }^{5}$ we find the description of a miracle of St. Nicolas during the reign of the Emperor Nicephorus I (802-8II). A few miracles of St. Nicolas are also alluded to by Andreas Cretensis in the seventh century. ${ }^{6}$

But this date is, strictly speaking, the latest to which we have a right to refer St. Nicolas' Vita and sea-miracles, and the earliest documents we possess are his representa: tions dating from the fifth century.? If we look into the text of the Life for proofs of its antiquity we shall find many. In it there is mention of the last persecution of the Christians by Diocletian. ${ }^{8}$ A miracle is stated to have taken place in the reign of Constantine the Great, ${ }^{\theta}$ another

1 Prof. Vesselovsky, Solomon i Kitouras, etc., St. Ptbg., 1872, p. xiv.

2 By Mr. Nutt, at the meeting of the Folk-lore Society of the $215 t$ of February 1894 .

4 Assemanus, l. c., p. 420.

- Theophanis Chronographia. Recensuit C. de Boor, Leipzig, 1883 ; see Nicolas, St. ${ }^{\circ}$ Migne, l. c., t. 97, p. I Igr. ${ }^{7}$ Görres, l. c. ${ }^{3}$ Simeonis Metaphrastae vita S. Nicolai; see Migne, l. c., pp.334335.

Ibid., p. $33^{8}$. 
miracle speaks of the dominion of the Vandals in Africa, ${ }^{1}$ and lastly, in a somewhat damaged text of a Vita different from that of Metaphrastes, we find unmistakable traces of the tradition of sacrificing oxen to St. George. ${ }^{2}$ In general, we can hardly doubt that the cult of St. Nicolas is one of the oldest cults of Christianity; it therefore seems to me very probable that his name should have so spread at the time Beozerulf was written ${ }^{3}$ (eighth to tenth century) as to become a common noun for a sea-monster. If we find Eastern coins and ornaments in Ireland and England, why should we not also find distant echoes of Eastern creeds?

The philological side of the question can hardly be considered difficult. We have already seen that the name of Nicolas in its nicknames still lives under the shape of Nickelman ${ }^{5}$ in Germany and $\mathrm{Nick}^{6}$ in England. The forms Nisse, Nissen, "must be explained", says Grimm, "from Niels, Nielsen, i.e., Nicolaus, Niclas"." From the root $n i q^{3}$ (= nick?) sprang all the other names of waterspirits-Mid. H. G. nix (niches); O. H. G. nikhus; A.S. nicor; O. Ic. nykr, etc.

There can be, therefore, only some doubt about the etymology of the presupposed roots, nick or nik or niq, themselves, which both Sanders ${ }^{9}$ and Dr. Skeat ${ }^{10}$ decline to give. Professor Earle says: "It (nicor) is a word of

1 Assemanus, l. c., p. 418.

2 See Mikola Ugodnik, etc., p. 5, etc.

3 Ten Brink, Beowulf, Strassburg, I888, S. 246; and Prof. T. Earle,

The Deeds of Beowulf, Oxford, 1892, pp. li-lii.

${ }^{4}$ Heyd, Geschichte des Levantenhandels, $1879, \mathrm{i}$, S. 97.

Grimm's Mythology, p. 514.

- Ibid., p. 488.

7 Ibid., p. 505.

${ }^{8}$ Fr. Kluge, An Etymological Dictionary of the German Language, London, 1891, p. 253. Compare Grimm's Deutsches Worterbuch, Leipzig, 1882, S. 86 r.

"Wörterbuch der deutschen Sprache, Leipzig, 1861; see Neck:

"Stamm fräglich." 10 Etymological Dictionary, Oxford, 1884, p. 392; see Nick : "Root
unknown." 
high antiquity, being found in all chief dialects"; but the repeated occurrence of the name in the whole of the Teutonic world can also be explained by the expansion of the Christian legend. Grimm derived the word from the root nig (Gr. $\nu i \xi \omega)=$ "to grow".2 Dr. Kluge offers the form niq (Gr. $\nu i \pi \tau \omega)=$ "to wash oneself." "Thus," says he, "Nix would mean originally a sea-monster that delights in bathing, a sea-spirit."3 E. H. Meyer ${ }^{4}$ proposes the form ur-germ. hneigjan = "to bend"; but in what way the notion of a sea-deity could develop itself out of the ideas of washing, or growing, or bending, is not explained by either, of the investigators just quoted.

It is, then, most probable that St. Nicolas, represented by all his popular nicknames-Klaus, Nickel, Nielsen, and Nick-penetrated into the Teutonic mythology, and gave his own name to the water-deity, the sea-monster, and even the devil.

But the etymology of proper names is a difficult problem, and Kuhn himself seems to have sometimes failed to solve it. ${ }^{5}$

1 L. c., p. 158.

2 Wörterbuch, S. 861.

3 L.C.

4 Germ. Mythen., S. 105.

- Gruppe, Die griechischen Culte und Mythen in ihrer Beziehungen zu den orientalischen Religionen, Leipzig, 1887, i, S. 103.

Professor Anichkof has not quite seized my point. I was struck by the fact that it is the final portion of the saint's name which has furnished the forms under which the name is now popularly known in the West (Klaus, Colas), for the assumption that the English Nick (in "Old Nick") is a shortened form of Nicolas is a purely questionbegging one. Obviously, if this was the case formerly, Professor Anichkof's contention that the Germanic water-god derived his name (and part of his attributes?) from the Christian saint goes by the board. Klaus could not have furnished Nichus. What is the historico-philological evidence as to the spread of the Greek name in Western Europe, and what in especial is the historico-ecclesiastical evidence as to the spread of his cult? If he was popular enough in the 5 th-8th centuries to rebaptise and transform a heathen waterdeity-and Professor Anichkof's theory postulates this-there must be many other evidences of that popularity in the West.-A. N. 